\title{
RESEARCH
}

Open Access

\section{Sphingosine 1-phosphate receptor 5 mediates the immune quiescence of the human brain endothelial barrier}

Ruben van Doorn ${ }^{1}$, Melissa A Lopes Pinheiro ${ }^{1}$, Gijs Kooij ${ }^{1}$, Kim Lakeman ${ }^{1}$, Bert van het Hof ${ }^{1}$, Susanne MA van der Pol', Dirk Geerts ${ }^{2}$, Jack van Horssen ${ }^{1}$, Paul van der Valk ${ }^{4}$, Elizabeth van der Kam³, Eric Ronken ${ }^{5}$, Arie Reijerkerk ${ }^{1}$ and Helga E de Vries ${ }^{1 *}$

\begin{abstract}
Background: The sphingosine 1-phosphate (S1P) receptor modulator FTY72OP (Gilenya ${ }^{\circledR}$ ) potently reduces relapse rate and lesion activity in the neuroinflammatory disorder multiple sclerosis. Although most of its efficacy has been shown to be related to immunosuppression through the induction of lymphopenia, it has been suggested that a number of its beneficial effects are related to altered endothelial and blood-brain barrier (BBB) functionality. However, to date it remains unknown whether brain endothelial S1P receptors are involved in the maintenance of the function of the BBB thereby mediating immune quiescence of the brain. Here we demonstrate that the brain endothelial receptor $\mathrm{S}_{\mathrm{P}} \mathrm{P}_{5}$ largely contributes to the maintenance of brain endothelial barrier function.
\end{abstract}

Methods: We analyzed the expression of $\mathrm{S} \mathrm{P}_{5}$ in human post-mortem tissues using immunohistochemistry. The function of $\mathrm{S1P}_{5}$ at the BBB was assessed in cultured human brain endothelial cells (ECS) using agonists and lentivirus-mediated knockdown of $\mathrm{S} \mathrm{P}_{5}$. Subsequent analyses of different aspects of the brain EC barrier included the formation of a tight barrier, the expression of BBB proteins and markers of inflammation and monocyte transmigration.

Results: We show that activation of $\mathrm{S1P}_{5}$ on cultured human brain $\mathrm{ECS}$ by a selective agonist elicits enhanced barrier integrity and reduced transendothelial migration of monocytes in vitro. These results were corroborated by genetically silencing $\mathrm{S1P}_{5}$ in brain ECs. Interestingly, functional studies with these cells revealed that $\mathrm{S}^{\mathrm{P}_{5}}$ strongly contributes to brain EC barrier function and underlies the expression of specific BBB endothelial characteristics such as tight junctions and permeability. In addition, $\mathrm{S}_{\mathrm{P}} \mathrm{P}_{5}$ maintains the immunoquiescent state of brain ECs with low expression levels of leukocyte adhesion molecules and inflammatory chemokines and cytokines through lowering the activation of the transcription factor NFKB.

Conclusion: Our findings demonstrate that $\mathrm{S}_{1} \mathrm{P}_{5}$ in brain ECs contributes to optimal barrier formation and maintenance of immune quiescence of the barrier endothelium.

Keywords: Sphingosine 1-phosphate (S1P) receptor, FTY720P, Blood-brain barrier, Neuroinflammation, Monocyte, Multiple sclerosis

\footnotetext{
* Correspondence: He.devries@vumc.n

'Department of Molecular Cell Biology and Immunology, VU University Medical Center, P.O.Box 7057, 1007 MB Amsterdam, The Netherlands

Full list of author information is available at the end of the article
} 


\section{Background}

The vasculature of the brain is specialized to function as a barrier to protect the central nervous system (CNS) by restricting entry of unwanted molecules and immune cells into the brain. This so-called blood-brain barrier (BBB) is composed of highly specialized brain endothelial cells (ECs) that line the capillary wall. These specialized ECs form a tight barrier by membrane efflux pumps that drive cellular exclusion of unwanted compounds and the expression of complex tight junctions [1-4], which actively limit cellular infiltration into the brain. The ECs are enclosed together with pericytes within the basement membrane onto which astrocytes firmly project their endfeet, thereby maintaining the barrier properties within the endothelium [5]. Strikingly, several neuroinflammatory and neurodegenerative diseases such as multiple sclerosis (MS), human immunodeficiency virus-associated dementia, capillary cerebral amyloid angiopathy and stroke are associated with an impaired function of the BBB [6-9]. Especially in MS, an altered BBB function leads to enhanced entry of immune cells and potentially toxic compounds into the CNS [10-12]. To date, it remains largely unknown which mechanisms underlie the altered BBB in such neurological disorders. The identification of targets to restore impaired barrier function may provide novel tools for treatment.

Sphingosine 1-phosphate (S1P) binding G-proteincoupled receptors (GPCRs) are thought to be involved in the regulation of the vasculature. In general, S1P signals through five GPCRs belonging to the endothelial differentiation gene (EDG) family which entails: $S 1 P_{1}$ (EDG-1), S1P 2 (EDG-5), S1P 3 (EDG-3), S1P 4 (EDG-6), and $\mathrm{S}_{1} \mathrm{P}_{5}$ (EDG-8). The S1P receptors are coupled to different $\mathrm{G}$-proteins resulting in divergent downstream signaling pathways. For example, $\mathrm{S}_{1} \mathrm{P}_{1}$ is proposed to couple to $G \alpha_{i}$ and $G \alpha_{o}$ whereas $\mathrm{S}_{1} P_{5}$ is through to interact with $G \alpha_{i}, G \alpha_{o}, G \alpha_{12}$, and $\mathrm{G \alpha}_{13}$ [13]. Consequently, signaling of S1P through its receptors affects a broad variety of signaling processes ranging from pathways involved in cell survival, proliferation, motility to differentiation. S1P receptors are essential in proper vascular development because deficiency of for example $\mathrm{S}_{1} \mathrm{P}_{1}$ results in early embryonic death due to defects in vascular maturation [14]. Moreover, numerous S1P-driven EC responses are reported and are found to be crucial for proper development, maintenance and regulation of peripheral vascular beds. S1P-mediated effects on the function of the endothelium are attributed to modulation of $\mathrm{S}_{1} \mathrm{P}_{1}$ and $\mathrm{S}_{1} \mathrm{P}_{3}$. S1P receptors are currently under extensive investigation because clinical trials demonstrate significant reduction of disease severity in neurological (autoimmune) disease models by targeting these receptors [15-19]. In addition, two phase III clinical trials (TRANSFORMS, FREEDOMS) concerning the S1P receptor modulator FTY720P $\left(\right.$ Gilenya $^{\circledR}$ ) for treatment of relapsing remitting MS deliver robust data demonstrating greatly reduced relapse rates, significant reduction in lesion activity, and lower risk of disability progression [20,21].

The recent availability of non-selective and selective S1P receptor agonists has led to an increasing amount of data about S1P receptor expression and their impact on cellular function in the CNS. Apparent CNS effects of S1P receptor modulators such as FTY720P and S1P itself are translated into for example reduced immune cell infiltration across the brain vasculature [19,22-24]. Recently, we demonstrated increased astrocytic $\mathrm{S}_{1} \mathrm{P}_{1}$ and $\mathrm{S} \mathrm{P}_{3}$ expression in active $\mathrm{MS}$ lesions and an antiinflammatory effect of FTY720P (active form of FTY720) on primary human astrocyte cultures [25]. Interestingly, although $\mathrm{S}_{1} \mathrm{P}_{1-4}$ receptors are widely expressed throughout the body, $\mathrm{S} \mathrm{P}_{5}$ expression is more or less restricted to the brain. It was therefore the aim of this study to investigate the involvement of $\mathrm{S}_{5} \mathrm{P}_{5}$ in underlying inflammatory processes in the CNS leading to MS lesion development. We here show that $\mathrm{S}_{5} \mathrm{P}_{5}$ is primarily expressed on brain ECs in human brain suggesting a key role of $\mathrm{S}_{5} \mathrm{P}_{5}$ in $\mathrm{BBB}$ maintenance. Our functional studies show that $\mathrm{S} \mathrm{P}_{5}$ is not only crucial for the maintenance of the BBB but is also a key modulator of endothelial inflammation processes. Ultimately, specific targeting of vascular $\mathrm{S} \mathrm{P}_{5}$ and subsequent repair of the $\mathrm{BBB}$ in patients with inflammatory disorders may have therapeutic benefits.

\section{Methods}

\section{Autopsy material}

Brain tissue from three non-neurological controls (Table 1) was obtained at rapid autopsy and immediately frozen in liquid nitrogen or fixed in formalin (in collaboration with The Netherlands Brain Bank, coordinator Dr. Huitinga). The Netherlands Brain Bank received permission to perform autopsies for the use of tissue and for access to medical records for research purposes from the Ethical Committee of the VU University Medical Center, Amsterdam, The Netherlands. Tissue samples from control cases without neurological disease were taken from the subcortical white matter. All controls, or their next of kin, had given informed consent for

Table 1 Clinical data of non-neurological controls

\begin{tabular}{lllccll}
\hline Case & $\begin{array}{l}\text { Age } \\
\text { (years) }\end{array}$ & $\begin{array}{l}\text { Type } \\
\text { of MS }\end{array}$ & Sex & $\begin{array}{l}\text { Post-mortem } \\
\text { delay (h:min) }\end{array}$ & $\begin{array}{l}\text { Disease } \\
\text { Duration } \\
\text { (years) }\end{array}$ & $\begin{array}{l}\text { Cause of } \\
\text { death }\end{array}$ \\
\hline Control & 89 & NA & $F$ & 6 & NA & Old age \\
Control & 89 & NA & M & 16 & NA & Dehydration \\
Control & 84 & NA & F & 5 & NA & Resp. failure
\end{tabular}

$\mathrm{NA}=$ not applicable; $m=$ male; $f=$ female. 
autopsy and the use of their brain tissue for research purposes.

\section{Immunohistochemistry}

For immunohistochemical analysis, 5- $\mu \mathrm{m}$ cryosections were processed and stained as described previously [26]. Briefly, sections were incubated overnight at $4{ }^{\circ} \mathrm{C}$ with primary antibodies against $\mathrm{S}^{\mathrm{P}} \mathrm{P}_{5}$ (1:200) (Santa Cruz Biotechnology, Santa Cruz, CA, USA and Imgenex, San Diego, CA, USA). Subsequently, sections were incubated with EnVision + Dual Link (DAKO, Glostrup, Denmark) according to the manufacturer's description. Diaminobenzidine tetrachloride (DAB; DAKO, Glostrup, Denmark) was used as the chromogen. Antibodies were diluted in PBS containing $0.1 \%$ bovine serum albumin (BSA; Boehringer Mannheim, Mannheim, Germany), which also served as a negative control. For colocalization studies, sections were incubated for 30 minutes with $5 \%$ goat serum. Subsequently, sections were incubated with primary antibodies as described above and with mouse antiCD31 (1:200; DAKO, Glostrup, Denmark). Sections were then incubated with goat anti-mouse Alexa 488 and goat anti-rabbit Alexa 594 secondary antibodies (1:400 Molecular Probes, Eugene OR, USA). Omission of primary antibodies served as a negative control. Incubation of tissue sections with isotype controls or no secondary antibody showed no immunoreactivity.

\section{Endothelial cell culture}

The human brain EC line hCMEC/D3 was kindly provided by Prof. P-O. Couraud (Institut Cochin, Université Paris Descartes, Paris, France) [27] and grown in Endothelial Cell Basal Medium-2 supplemented with hEGF, hydrocortisone, GA-1000, FBS, VEGF, hFGF-B, $\mathrm{R}^{3}$-IGF1, ascorbic acid and $2.5 \%$ fetal calf serum (FCS; EGM-2, Lonza, Basel, Switzerland). Cells were cultured as described before [28].

\section{Lentiviral shRNA for S1P5 knockdown}

Selective gene knockdown was obtained by using a vector-based short hairpin (sh) RNA technique as described before [29]. Plasmids encoding $\mathrm{S}_{1} \mathrm{P}_{5}$-specific shRNAs were obtained from Sigma (TRCN0000004752, St Louis, MO, USA). Recombinant lentiviruses were produced by co-transfecting subconfluent HEK 293 T cells with the specific expression plasmids and packaging plasmids (pMDLg/pRRE, pRSV-Rev and pMD2G) using calcium phosphate as a transfection reagent. HEK $293 \mathrm{~T}$ cells were cultured in DMEM supplemented with $10 \%$ FCS, $1 \%$ penicillin/streptomycin, in a $37{ }^{\circ} \mathrm{C}$ incubator with $5 \% \mathrm{CO}_{2}$. Infectious lentiviruses were collected 48 hours after transfection and stored at $-80{ }^{\circ} \mathrm{C}$. Subsequently, lentiviruses expressing $\mathrm{S}_{1} \mathrm{P}_{5}$-specific shRNA were used to transduce hCMEC/D3 cells. Control cells were generated by transduction with lentivirus expressing non-targeting shRNA (SHC002, Sigma, St Louis, MO, USA). Forty-eight hours after infection of hCMEC/ D3 cells with the shRNA-expressing lentiviruses, stable cell lines were selected by puromycin treatment $(2 \mu \mathrm{g} /$ $\mathrm{ml}$ ). The expression knockdown efficiency was determined by quantitative PCR (qPCR).

\section{Quantitative PCR}

All oligonucleotides were synthesized by Ocimum Biosolutions (Ocimum Biosolutions, Ijsselstein, The Netherlands) (Table 2), RNA was isolated using the Aurum ${ }^{\mathrm{TM}}$

Table 2 Primers

\begin{tabular}{|c|c|c|}
\hline Primer & Sequence Forward & Sequence Reverse \\
\hline$\overline{S 1 P_{1}}$ & 5'-TGCGGGAAGGGAGTATGTTT-3' & 5'-CGATGGCGAGGAGACTGAAC-3' \\
\hline $\mathrm{S}_{1} \mathrm{P}_{2}$ & 5'-TCTCTACGCCAAGCATTATGTGC-3' & 5'-TGGCCAACAGGATGATGGA-3' \\
\hline $\mathrm{S}_{1} \mathrm{P}_{3}$ & 5'-TGCAGCTTCATCGTCTTGGAG-3' & 5'-GCCAATGAAAAAGTACATGCGG-3' \\
\hline $\mathrm{S}_{1} \mathrm{P}_{5}$ & 5'-CCTTGGTGGCATGTTGGG-3' & 5'-GGGTTCAGAAGTGAGTTGGG-3' \\
\hline GLUT & 5'-GCCCCTGTGAAGATTGAGAG-3' & 5'-CCCGAAGCAGCCAATCC-3' \\
\hline BCRP & 5'-AGATGGGTTTCCAAGCGTTCAT-3' & 5'-CCAGTCCCAGTACGACTGTGACA-3' \\
\hline PGP & 5'-GTCCCAGGAGCCCATCCT-3' & 5'-CCCGGCTGTTGTCTCCATA-3' \\
\hline VE-cadherin & 5'-TGACGTGAACGACAACTGGC-3' & 5'-GACGCATTGAACAACCGATG-3' \\
\hline Claudin-5 & 5'-GCCCCTGTGAAGATTGAGAG-3' & 5'-CCCGAAGCAGCCAATCC-3' \\
\hline TNF-a & 5'-CCAAGCCCTGGTATGAGCC-3' & 5'-GCCGATTGATCTCAGCGC-3' \\
\hline $\mathbb{I L}-1 \beta$ & 5'-GCTGATGGCCCTAAACAGATG-3' & 5'- GCAGAGGTCCAGGTCCTGG-3' \\
\hline IL-8 & 5'-TGAGAGTGGACCACACTGCG-3' & 5'-TCTCCACAACCCTCTGCACC-3' \\
\hline MCP-1 & 5'-ATCTCAGTGCAGAGGCTCGC-3' & 5'-GCACAGATCTCCTTGGCCAC-3' \\
\hline VCAM & 5'-TGAAGGATGCGGGAGTATATGA-3 & '5'-TTAAGGAGGATGCAAAATAGAGCA-3 \\
\hline ICAM & 5'-TAGCAGCCGCAGTCATAATGGG-3' & '5'-AGGCGTGGCTTGTGTGTTCG-3 \\
\hline
\end{tabular}


Total RNA capture kit (Biorad, CA, USA) according to the manufacturer's instructions. cDNA was synthesized with the Reverse Transcription System kit (Promega, Madison, WI, USA) following manufacturer's guidelines as described previously [30]. qPCR reactions were performed in an ABI7900HT sequence detection system with the SYBR Green method (Applied Biosystems, Carlsbad, CA, USA). Obtained expression levels of transcripts were normalized to GAPDH expression levels.

\section{Western blot}

Cell homogenates were prepared by replacing the culture medium with sodium dodecyl sulfate (SDS) sample buffer containing 5\% ß-mercaptoethanol and subsequent heating at $95{ }^{\circ} \mathrm{C}$ for 5 minutes. Samples were separated by SDS-PAGE and blotted onto nitrocellulose membranes. Membranes were blocked with Odyssey block buffer and incubated with an antibody against $\mathrm{S} \mathrm{P}_{5}$ (Santa Cruz Biotechnology, Santa Cruz, CA, USA). Binding was visualized using the Odyssey ${ }^{\circledR}$ Infrared Imaging System after application of IgG labeled with Infrared dye (IRdye) 800 (Rockland Immunochemicals, Gilbertsville, $\mathrm{PA}, \mathrm{USA}$ ). For quantification, $\mathrm{S}_{5} \mathrm{P}_{5}$. protein levels were corrected for tubulin using a specific anti-tubulin antibody (Cedarlane, Canada). The basal expression of p65 in $\mathrm{S}_{1} \mathrm{P}_{5}$ knockdown and control cells was assessed with a rabbit anti-p65 antibody (Cell Signaling Technology, Danvers, MA, USA) followed by secondary donkey antirabbit 800 (IRDye). Protein expression was normalized to beta-actin (Santa Cruz Biotechnology, Santa Cruz, CA, USA) detected with donkey anti-goat 680 (IRDye).

\section{Immunocytochemistry}

Transduced (mock and $\mathrm{S}_{\mathrm{P}}$ ) hCMEC/D3 cells were plated in collagen coated $\mu$-slide 8 well slides (Ibidi, Martinsried, Germany) and cultured as described before. Upon confluence, cells were cultured in Endothelial Cell Basal Medium-2 containing 2,5\% human serum and $5 \mathrm{ng} / \mathrm{ml}$ basic fibroblast growth factor (bFGF) overnight and fixed in $4 \%$ formaldehyde (Sigma, St Louis, MO, USA) in PBS (Gibco) in the presence of $0.5 \%$ Triton (Sigma, St Louis, MO, USA). Cells were washed and blocked with PBS containing 0.1\% BSA (Sigma, St Louis, MO, USA) and 5\% normal goat serum (NGS). Subsequently, cells were incubated with mouse anti-VEcadherin primary antibody (1:500: Becton \& Dickinson, San Jose, CA, USA) in PBS containing 0.1\% BSA and 5\% NGS overnight. Cells were washed and incubated with goat anti-mouse Alexa 488 secondary antibody (1:400: Molecular Probes, Eugene OR, USA). After washing the cells with PBS, rhodamine phalloidin (1:300) (Molecular Probes, Eugene OR, USA) was used for F-actin staining and Hoechst (1:1000 Molecular Probes, Eugene OR, USA) for nuclear staining.

\section{Electrical cell-substrate impedance sensing}

Transendothelial electric resistance in confluent monolayers of hCMEC/D3 cells was measured using an electrical cell-substrate impedance sensing (ECIS) model ZTheta (Applied BioPhysics, NY, USA) and 8W10E + arrays. In short, $300 \mu \mathrm{l}$ cell suspension $\left(1,0 \times 10^{5}\right.$ cells $)$ was added to in each well in Endothelial Cell Basal Medium-2 supplemented with 2,5\% human serum and 5 $\eta \mathrm{g} / \mathrm{ml}$ bFGF. Cells were seeded in medium containing dimethyl sulfoxide (DMSO; $1 \mu \mathrm{M}$ serving as vehicle control), FTY720P $(1 \mu \mathrm{M})$, or a $\mathrm{S} \mathrm{P}_{5}$ selective agonist $(1 \mu \mathrm{M}$ compound 18, a kind gift from Professor Stephen Hanessian, Université de Montreal, Montreal, Canada) [31]. Prior to seeding the collagen-coated ECIS arrays were equilibrated with growth medium and $\mathrm{Rb}$ values were calculated using ECIS software version 1.2.55.0 PC.

\section{Permeability of the brain endothelial layer}

Permeability of human brain EC monolayers was analyzed as described previously [28]. hCMEC/D3 and hCMEC/D3 $\mathrm{S} 1 \mathrm{P}_{5}$ knockdown cells were seeded at confluence onto collagen-coated Costar Transwell filter (pore-size $0.4 \mu \mathrm{m}$; Corning Incorporated, Corning, NY, USA) in growth medium containing 2.5\% FCS and grown for 4 days. Paracellular permeability to FITCdextran $(150 \mathrm{kDa}, 500 \mu \mathrm{g} / \mathrm{ml}$ in culture medium; Sigma, St Louis, MO, USA-Aldrich) in the apical to basolateral direction was assayed at various time points. Samples were collected from the acceptor chambers for measurement of fluorescence intensity using a FLUOstar Galaxy microplate reader (BMG Labtechnologies, Offenburg, Germany), excitation $485 \mathrm{~nm}$ and emission $520 \mathrm{~nm}$.

\section{Monocyte migration}

Human blood monocytes were isolated from buffy coats of healthy donors (Sanquin, Blood Bank, Amsterdam, NL) by Ficoll gradient and CD14-positive beads [32]. Control and $\mathrm{S} \mathrm{P}_{5}$ knockdown hCMEC/D3 cells were seeded at confluence onto collagen-coated Costar Transwell filters (pore-size $5 \mu \mathrm{m}$; Corning Incorporated, Corning, NY, USA) in growth medium containing 2.5\% FCS and were grown for 4 days. ECs were exposed to DMSO $(1 \mu \mathrm{M})$ as a vehicle control, FTY720P $(1 \mu \mathrm{M})$ or $\mathrm{S1P}_{5}$ agonist $(1 \mu \mathrm{M})$ agonist for 16 hours and washed prior to addition of monocytes [31]. Hereafter, $100 \mu \mathrm{l} 1.6 \times 10^{6} /$ $\mathrm{ml}$ primary human monocytes suspended in Endothelial cell Growth medium-2 containing 2,5\% FCS were added to the upper compartment for 8 hours at $37^{\circ} \mathrm{C}, 5 \% \mathrm{CO}_{2}$ in air. Next, the suspension in the lower compartment containing transmigrated monocytes was harvested and quantified using anti-CD14 beads (Flow-count fluorospheres, BeckmanCoulter, Inc., Brea, CA, USA) and subsequent FACScan flow cytometer (Becton \& Dickinson, San Jose, CA, USA) analyses. 


\section{Monocyte adhesion assay}

Monocyte adhesion to confluent monolayers of control and S1P5 knockdown hCMEC/D3 cells was analyzed by using primary human monocytes isolated as described before. Human monocytes were fluorescently labeled with $0.5 \mu \mathrm{M}$ calcein-Am (Molecular Probes, Eugene OR, USA) and suspended in RPMI + 0.5\% BSA + $25 \mathrm{mM}$ Hepes to a final concentration of $1 \times 10^{6}$ cells [33]. A standard curve of human monocytes was made with 0 , $12.5,25,50$, and $100 \%$ of this cell suspension. ECs were washed and monocytes were added and incubated for 5 , 15,30 , and 60 minutes in a $37{ }^{\circ} \mathrm{C}$ incubator with $5 \%$ $\mathrm{CO}_{2}$. Non-adherent cells were removed and adherent cells were lysed with $0.1 \mathrm{M} \mathrm{NaOH}$. Fluorescence intensity was measured (FLUOstar Galaxy, BMG Labtechnologies, Offenburg, Germany; excitation $480 \mathrm{~nm}$, emission $520 \mathrm{~nm}$ ) and the number of adhered monocytes was calculated using the standard [33].

\section{Flow cytometric analysis}

Control and $\mathrm{S} \mathrm{P}_{5}$ knockdown hCMEC/D3 cells were detached from 24-well culture plates, washed and incubated with monoclonal mouse anti-intercellular adhesion molecule-1(ICAM-1) (Rek-1, $5 \mu \mathrm{g} / \mathrm{ml}$, a kind gift from the Department of Tumour Immunology, University Medical Center St. Radboud, Nijmegen, The Netherlands) or mouse anti-vascular cell adhesion molecule-1 (VCAM-1; AbD Serotec, UK) for 30 minutes at $4{ }^{\circ} \mathrm{C}$ [34]. Binding was detected using goat anti-mouse Alexa 488 (Molecular Probes, Eugene, OR). Omission of primary antibodies served as negative control. To investigate the role of Nuclear factor kappa-light-chain-enhancer of activated $\mathrm{B}$ cells $(\mathrm{NF} \kappa \mathrm{B})$ in the enhanced inflammatory status of $\mathrm{S} \mathrm{P}_{5}$ knockdown cells, the cells were treated for 16 hours with $4 \mu \mathrm{M}$ NFkB inhibitor Bay 11-7085 (Sigma, $\mathrm{MO}$, USA) or vehicle control. Fluorescence intensity was measured using a FACS Calibur flow cytometer (Becton \& Dickinson, San Jose, CA, USA). The mean fluorescence intensity was used as a measure for the expression of ICAM-1 and VCAM-1.

\section{Statistical analysis}

Data are presented as \pm SEM and were analyzed statistically by means of single-column $t$-test. Statistical significance was defined as ${ }^{*} P<0.05$, ${ }^{* *} P<0.002$, and ${ }^{* * *} P<0.001$.

\section{Results}

$\mathrm{S} \mathrm{P}_{5}$ is highly expressed by brain capillaries in the human brain

The expression of the $\mathrm{S} \mathrm{P}_{5}$ was analyzed in the white matter of non-neurological control patients. Immunohistochemical staining with the two different anti-S1P antibodies, clone H-88 (Santa Cruz) (Figure 1a) and
IMG-71372 (Imgenex) (Figure 1b), essentially yield identical results. Both antibodies revealed that human brain capillaries in the white and the gray matter (not shown) constitutively express $\mathrm{S}_{1} \mathrm{P}_{5}$. Colocalization studies using the endothelial marker CD31 (PECAM-1; Figure 1c) together with antibodies against $\mathrm{S}_{5} \mathrm{P}_{5}$ (Figure 1d) identified ECs as the most predominant $\mathrm{S} \mathrm{P}_{5}$ expressing cell type within the human brain (Figure 1e). Gene expression analysis of the different S1P receptors in hCMEC/D3 cells indicated that brain ECs express all S1P receptors except $\mathrm{S}_{4} \mathrm{P}_{4}$ at different levels $\left(\mathrm{S}_{1} \mathrm{P}_{1}>\mathrm{S}_{1} \mathrm{P}_{5}>\mathrm{S}_{1} \mathrm{P}_{3}>\right.$ $\mathrm{S} \mathrm{P}_{2}$ with $\mathrm{S}_{1} \mathrm{P}_{1}$ being the highest; Figure $\left.1 \mathrm{f}\right)$.

\section{FTY720P and a selective $\mathrm{S}_{1} \mathrm{P}_{5}$ agonist enhance transendothelial electrical resistance}

To investigate the role of $\mathrm{S} \mathrm{P}_{5}$ in brain EC barrier function, we measured paracellular resistance formation by hCMEC/D3 cells while exposed to either FTY720P or the selective $\mathrm{S} \mathrm{P}_{5}$ agonist [31] by means of ECIS. Our results show that $\mathrm{S} 1 \mathrm{P}$ receptor activation by the nonselective S1P receptor agonist FTY720P significantly increases barrier formation in comparison with control cells (Figure 2a). At the same time, stimulation of the brain ECs with the selective $\mathrm{S} \mathrm{P}_{5}$ agonist also significantly enhanced barrier formation in comparison to controls (Figure 2b), indicating that $\mathrm{S}_{1} \mathrm{P}_{5}$ agonism modulates barrier formation. Moreover, treatment of brain endothelial monolayers with both the non-selective S1P receptor modulator FTY720P and the selective $\mathrm{S}_{1} \mathrm{P}_{5}$ agonist significantly reduced permeability of hCMEC/D3 cells for FITC-dextran (70kD) by $63.2 \% \pm 4.6$ and $61.7 \pm 5.0$, respectively (Figure $2 \mathrm{c}$ ).

\section{S1P agonism reduces transendothelial migration of monocytes}

We next studied the effect of FTY720P and the selective $\mathrm{S} \mathrm{P}_{5}$ agonist on a hallmark of neuroinflammation, namely monocyte migration across the brain EC barrier. hCMEC/D3 cells were exposed to FTY720P or the selective $\mathrm{S} \mathrm{P}_{5}$ agonist for 24 hours prior to the addition of primary human monocytes. In concordance with the results described above, treatment with both FTY720P (Figure $3 \mathrm{a}$ ) and the selective $\mathrm{S} \mathrm{P}_{5}$ agonist (Figure $3 \mathrm{~b}$ ) resulted in reduced transmigration of monocytes as compared to vehicle-treated hCMED/D3 cells. It is of interest that the reduced transendothelial migration of monocytes across treated ECs coincided with a decreased mRNA expression of the leukocyte adhesion molecule VCAM-1 (Figure 3c) and increased expression of the cell-cell junction protein VE-cadherin (Figure 3d), suggesting that $\mathrm{S} \mathrm{P}_{5}$ agonism reduced the inflammatory status of the brain endothelium. 

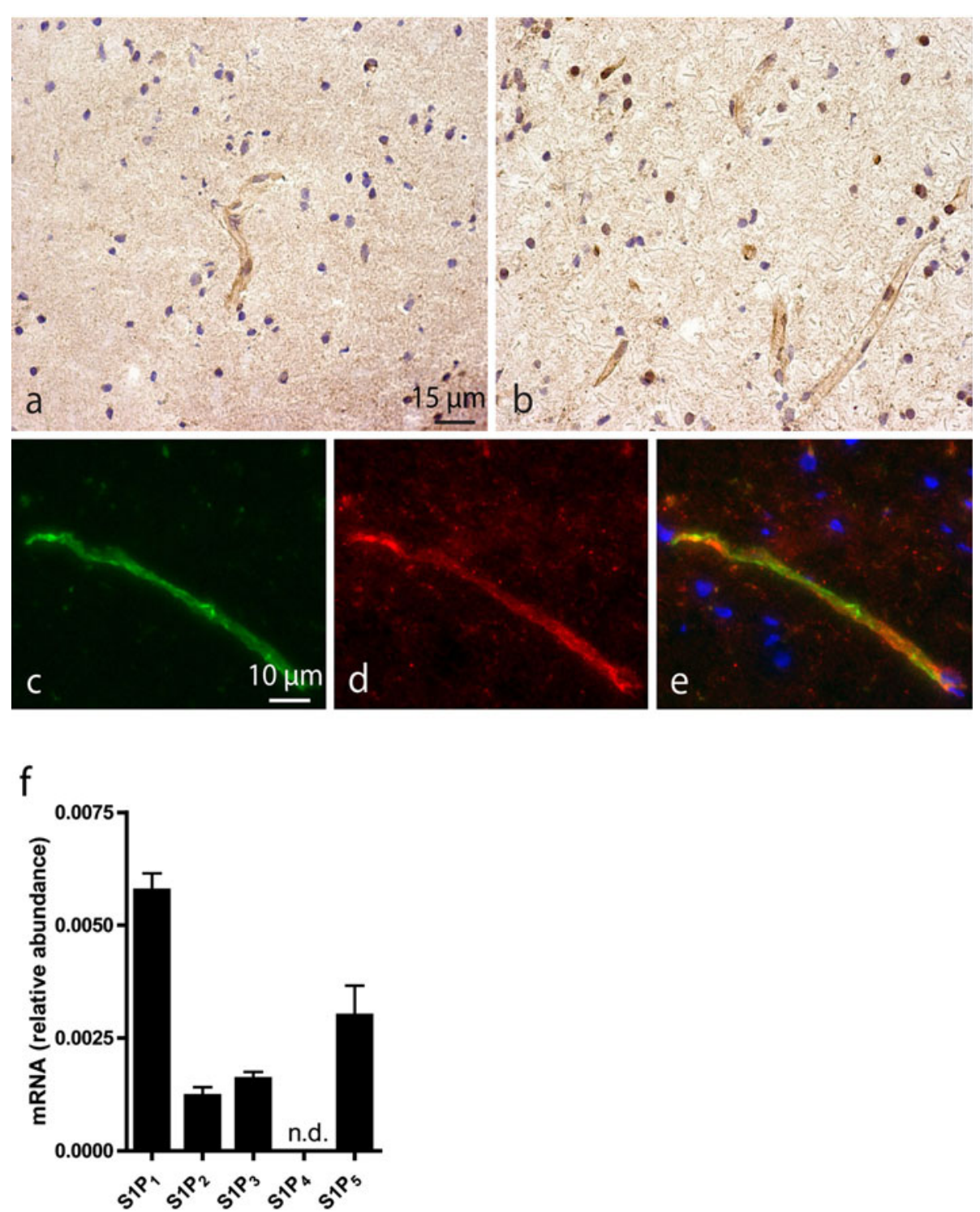

Figure $1 \mathbf{S} P_{5}$ is expressed in the human cerebrovasculature. Capillaries in white matter from non-neurological human controls show strong $\mathrm{S}_{1} \mathrm{P}_{5}$ expression. Human $\mathrm{S1P}_{5}$ expression was determined with either the Santa Cruz (a) or the Imgenex (b) antibody both showing similar staining patterns. Colocalization studies with the EC marker CD31 (c) confirmed that ECs express significant levels of S1P $\mathrm{P}_{5}$ (d) in human brain capillaries (e). S1P receptor RNA expression levels of hCMEC/D3 cells were determined by qPCR. S1P 1 expression was most abundant while there was no detectable level of $\mathrm{S}_{1} \mathrm{P}_{4}$ expression. Receptor expression was detected in the following order: $\mathrm{S}_{\mathrm{P}} \mathrm{P}_{1}>\mathrm{S}_{1} \mathrm{P}_{5}>\mathrm{S}_{1} \mathrm{P}_{3}>\mathrm{S}_{1} \mathrm{P}_{2}$ where $\mathrm{S}_{1} \mathrm{P}_{1}$ expression level was set at 100\% (f). RNA encoding for S1P4 was undetectable (n.d.). Data represent \pm SEM of three independent experiments.

\section{S1P5 is essential for the brain EC barrier phenotype}

To further elucidate the mechanism of the $\mathrm{S} \mathrm{P}_{5}$ at the brain endothelium, we generated a brain EC line (hCMED/D3 subclone E2) with reduced expression of

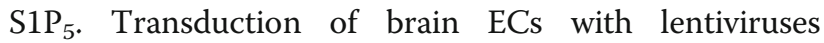
expressing a $\mathrm{S}_{1} \mathrm{P}_{5}$-specific shRNAs reduced the expression of $\mathrm{S}_{5} \mathrm{P}_{5}$ as determined by qPCR to undetectable levels (Figure $4 \mathrm{a}$ ). Protein levels of $\mathrm{S}_{1} \mathrm{P}_{5}$ were reduced by $43 \%$ (Figure $4 \mathrm{~b}$ ). Of note, $\mathrm{S}^{\mathrm{P}} \mathrm{P}_{5}$ knockdown cells also displayed reduced expression of other S1P receptors including $\mathrm{S}_{1} \mathrm{P}_{1}, \mathrm{~S}_{1} \mathrm{P}_{2}$ and $\mathrm{S}_{1} \mathrm{P}_{3}$ (Figure $4 \mathrm{c}$ ). These findings suggest that $\mathrm{S} \mathrm{P}_{5}$ regulates the expression of other S1P receptors.

Next, ECIS analysis was performed to determine the function of $\mathrm{S} \mathrm{P}_{5}$ in brain $\mathrm{EC}$ barrier formation. Interestingly, $\mathrm{S} \mathrm{P}_{5}$ knockdown cells revealed reduced barrier integrity compared to control cells (Figure 5a). To further delineate function of $\mathrm{S} \mathrm{P}_{5}$ on brain endothelial function, we studied various other properties that are associated with $\mathrm{BBB}$ functioning. First, $\mathrm{S} \mathrm{P}_{5}$ knockdown cells were more permeable to FITC-dextrans compared to control cells (Figure 5b), illustrating enhanced leakiness of the 


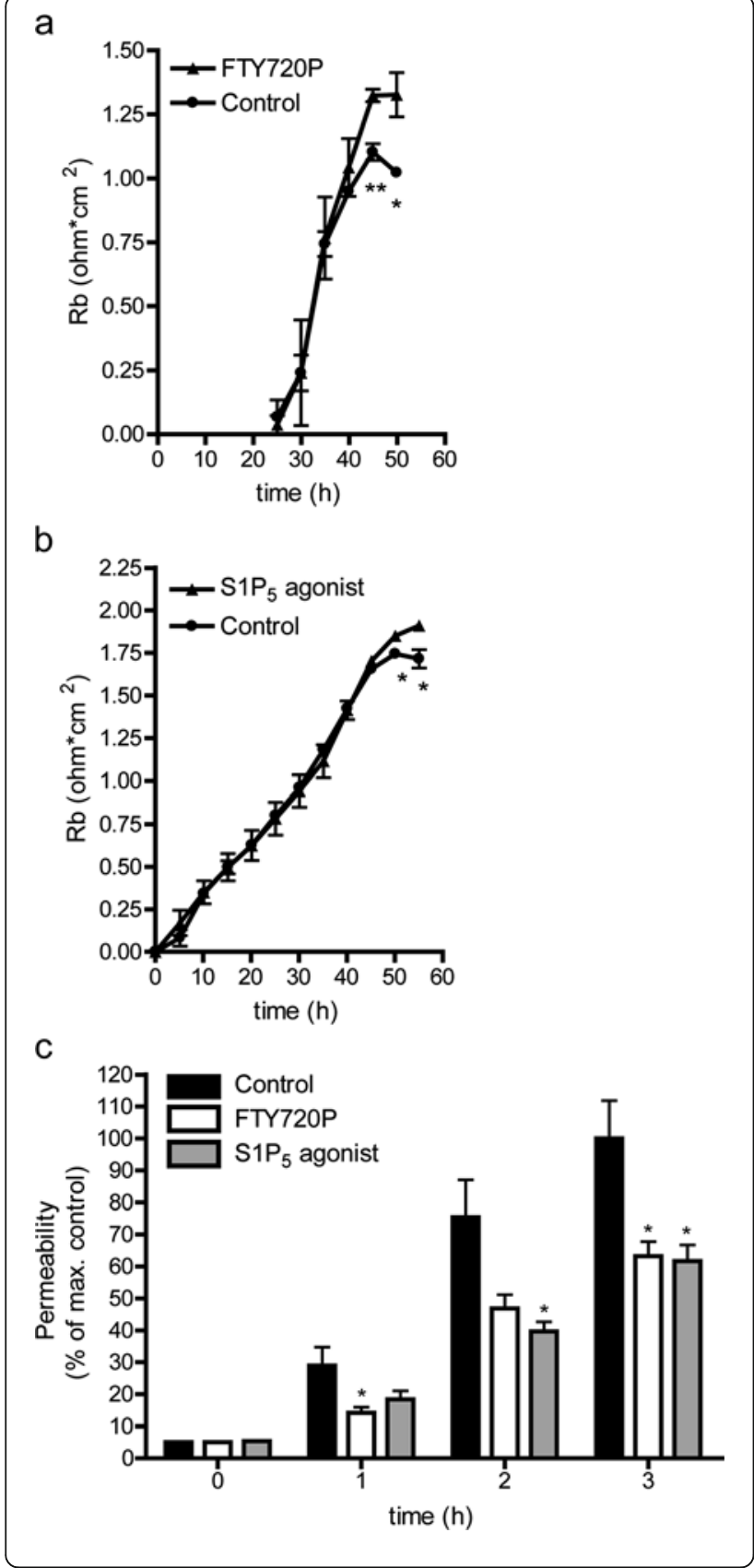

brain endothelial layer. Second, and in accordance with these data, $\mathrm{S} \mathrm{P}_{5}$ knockdown ECs displayed reduced expression levels of tight junction and adherent junctionassociated proteins such as claudin-5 and VE-cadherin (Figure 5c). Our analyses further show that key BBBassociated transporter proteins like the nutrient transporter for glucose (GLUT-1), and the ATP-binding cassette $(\mathrm{ABC})$ transporters P-glycoprotein (Pgp) and breast cancer resistant protein-1 (BCRP-1) were significantly decreased (Figure 5d) upon $\mathrm{S}_{5} \mathrm{P}_{5}$ knockdown. Consistent with the observed reduced VE-cadherin expression
Figure $2 \mathrm{~S} \mathrm{P}_{5}$ activation enhances barrier endothelial integrity. S1P receptor modulators were used to determine their effect of the transendothelial electrical resistance (TEER) as assayed through ECIS. (a) The non-selective S1P receptor modulator FTY720P $\left(10^{-6} \mathrm{M}\right.$ in DMSO) enhanced the TEER of hCMEC/D3 cells to $1.32 \mathrm{ohm}$. $\mathrm{cm}^{2} \pm 0.02, \mathrm{n}=3$ compared to vehicle control at final time point (1.10 ohm. $\mathrm{cm}^{2} \pm 0.03, \mathrm{n}=3$ ). Statistical significance (t-test) is indicated with asterisks: ${ }^{*} P<0.05$ and ${ }^{* *} P<0.005$. (b) The selective $\mathrm{S} \mathrm{P}_{5}$ agonist $\left(10^{-6} \mathrm{M}\right.$ in DMSO) enhanced TEER of hCMEC/D3 cells to $1.91 \mathrm{ohm} . \mathrm{cm}^{2} \pm 0.03, \mathrm{n}=4$ at final time point compared to vehicle control (1.72 ohm. $\mathrm{cm}^{2} \pm 0.05, \mathrm{n}=4$ ) (B). The Rb values represent the mean \pm SEM of four independent experiments. Statistical significance ( $t$-test) is indicated with asterisks: ${ }^{*} P<0.05$. (c) Both the nonselective S1P receptor modulator FTY720P $\left(10^{-6} \mathrm{M}\right.$ in DMSO) and the selective $\mathrm{S}_{1} \mathrm{P}_{5}$ agonist $\left(10^{-6} \mathrm{M}\right.$ in DMSO) reduced permeability of hCMEC/D3 cells for FITC-dextran (FD 70) by $63.2 \% \pm 4.6(n=4)$ and $61.7 \% \pm 5.0(n=4)$, respectively. Fluorescence intensity values represent mean \pm SEM of four individual experiments with hCMEC/ D3 value at 5 hours set at $100 \%(100.0 \% \pm 11.8, n=4)$. Statistical significance ( $t$-test) is indicated with asterisks: ${ }^{*} P<0.05$.

level in $\mathrm{S} \mathrm{P}_{5}$ knockdown cells, we found impaired VEcadherin protein localization to the junctions in the $\mathrm{S} \mathrm{P}_{5}$ knockdown cells (Figure 5e). Together, these data show that $\mathrm{S}_{1} \mathrm{P}_{5}$ has a crucial role in the maintenance of the barrier phenotype in brain ECs.

\section{$\mathrm{S}_{1} \mathrm{P}_{5}$ contributes to the immune quiescence state of the brain EC barrier}

Under normal conditions, the brain endothelium promotes immunoquiescence of the brain by a low expression of cell adhesion molecules and undetectable detection of the production of proinflammatory cytokines and chemokines, thereby limiting attraction and subsequent transendothelial migration of leukocytes.

To investigate the role of $\mathrm{S} \mathrm{P}_{5}$ in the inflammatory status of the brain endothelium, we studied gene expression levels of cytokines and chemokines known to be involved in the neuroinflammatory attack such as the chemokines monocyte chemoattractant protein-1 (MCP1: CCL2) and interleukin-8 (IL-8) and the proinflammatory cytokines interleukin-1 $\beta$ (IL-1 $\beta$ ), and tumor necrosis factor- $\alpha$ (TNF- $\alpha$ ). Upon $\mathrm{S}_{1} \mathrm{P}_{5}$ knockdown, mRNA levels of MCP-1 and IL- 8 as well as the levels of TNF- $\alpha$ and IL-1 $\beta$ increased dramatically (Figure 6a,b).

Interestingly, our results showed that activation of S1P receptors, and in particular $\mathrm{S}_{1} \mathrm{P}_{5}$, reduced the expression of adhesion molecules and enhanced the capacity of brain ECs to prevent monocyte passage (Figure 3). We next determined the function of $\mathrm{S}_{5} \mathrm{P}_{5}$ in these distinct aspects of the BBB. As expected, knockdown of the $\mathrm{S} \mathrm{P}_{5}$ in brain endothelium enhanced the adhesion of monocytes to, and migration of, monocytes through the endothelium when compared to mock and control hCMEC/ D3 cells (Figure 7a,b). 


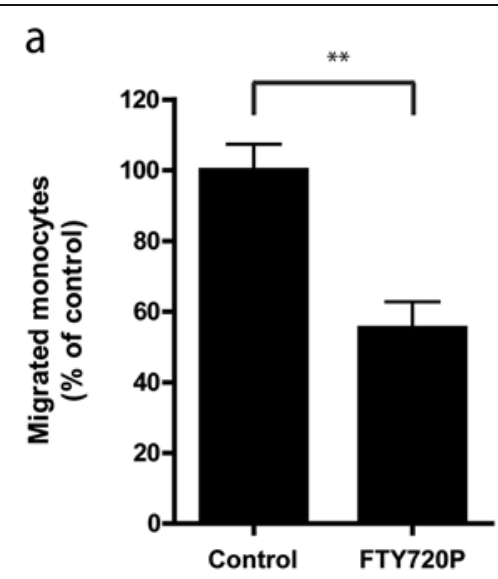

b

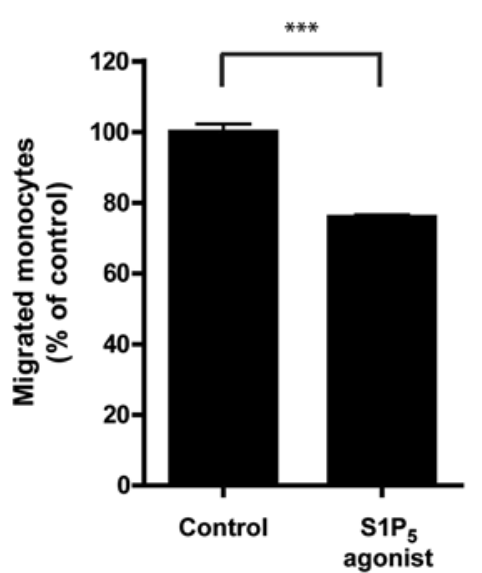

C

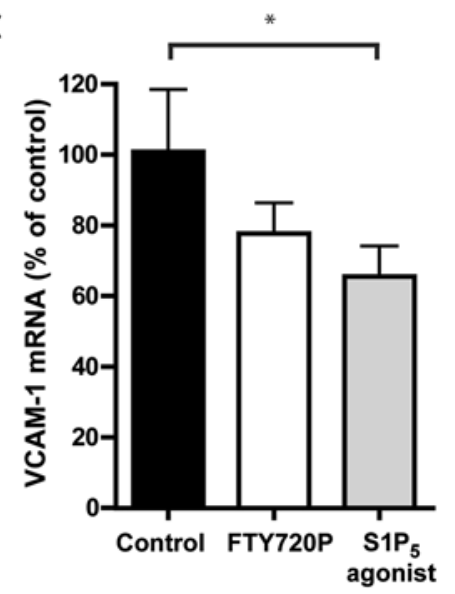

d

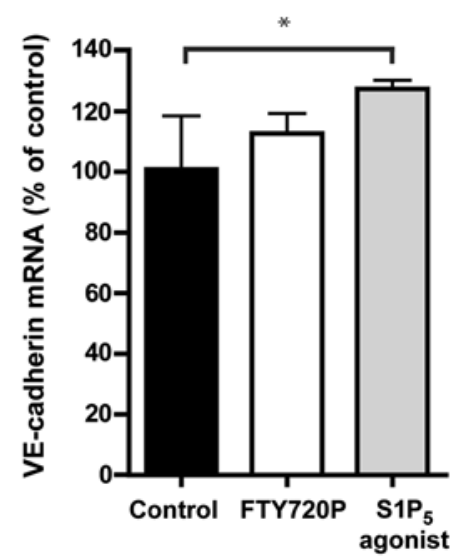

Figure 3 Endothelial $\mathrm{S}_{1} \mathrm{P}_{5}$ activation decreases monocyte transmigration. FTY720P $\left(10^{-6} \mathrm{M}\right.$ in DMSO; a) and a $\mathrm{S}_{5} \mathrm{P}_{5}$ agonist $\left(10^{-6} \mathrm{M}\right.$ in DMSO; b) were added to confluent monolayers of hCMEC/D3 cells for 24 hours. Monocyte migration was assayed by time lapse microscopy, FTY720P treatment of the brain ECs reduced monocyte migration to $55.3 \% \pm 7.42(n=3)$ compared to control $(106.0 \% \pm 6.14 n=3 ; \mathbf{a})$ and treatment with the selective $\mathrm{S}_{1} \mathrm{P}_{5}$ agonist reduced monocyte migration to $75.9 \% \pm 0.68 \mathrm{n}=3 ; \mathbf{b}$ ). Both FTY720P and $\mathrm{S}_{\mathrm{P}}$ agonist treated cells show reduced VCAM-1 expression (control: 100.0\% $\pm 17.0 ; \mathrm{S} \mathrm{P}_{5}$ agonist $64.8 \% \pm 8.9, \mathrm{n}=3 ; \mathbf{c}$ ) and increased VE-cadherin expression (control: $100.0 \% \pm 8.5 ; S_{1} P_{5}$ agonist: $126.3 \% \pm 2.6, n=3$; d). Values represent the mean \pm SEM of three individual experiments each performed in triplicate with controls set at $100 \%$. Statistical significance (t-test) is indicated with asterisks: ${ }^{*} P<0.05{ }^{*} P<0.002$ and ${ }^{* *} P<0.001$.

To reveal the underlying mechanism of this enhanced monocyte-endothelial interaction we next determined the expression levels of adhesion molecules ICAM-1 and VCAM-1 which are both known to be involved in the adhesion and migration of monocytes [35]. Our results show that both gene and protein expression levels of VCAM-1 and ICAM-1 were significantly increased in

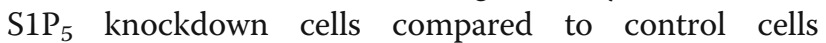
(Figure 7c,d). Together, these findings indicate that steady-state presence of cell surface $\mathrm{S} \mathrm{P}_{5}$ strongly contributes to the immune quiescence state of the BBB.

The inflammatory phenotype is partly mediated by NF-KB activation

As both ICAM-1 and VCAM-1 expression are under the control of the NF- $\mathrm{kB}$ signaling pathway, we studied whether brain endothelial $\mathrm{S}_{1} \mathrm{P}_{5}$ exert their antiinflammatory control through NF- $\mathrm{kB}$. First we determined the regulation of the total $\mathrm{p} 65$ subunit of NF- $\mathrm{kB}$ protein content by western blot. As shown in Figure 8a, the $\mathrm{S} \mathrm{P}_{5}$ knockdown cells have an increased basal expression of the p65 subunit of NF-kB when compared to control cells. This increased NF- $\kappa B$ content, which might underlie the increased expression of adhesion molecules, strongly suggests that $\mathrm{S} \mathrm{P}_{5}$ modulation is involved in immune quiescence of brain ECs mediated by inhibition of NF- $\kappa$ B. The selective NF- $\mathrm{kB}$ inhibitor Bay 11-7085 significantly reduced the gene expression levels of both ICAM-1 and VCAM-1 (Figure 8b,c). Interestingly, addition of Bay-

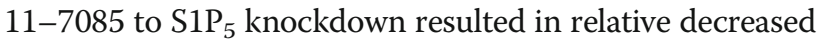
gene expression levels of ICAM-1 and VCAM-1 compared to the mock control cells. To reveal the effect of 
a

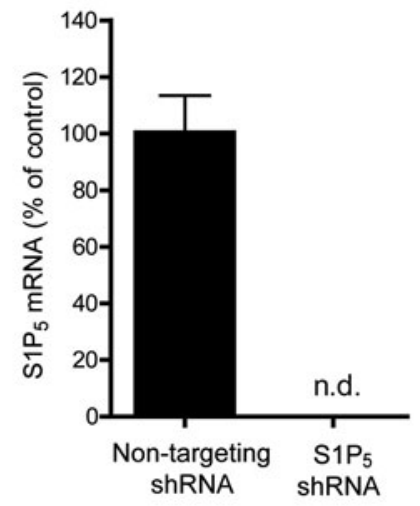

C

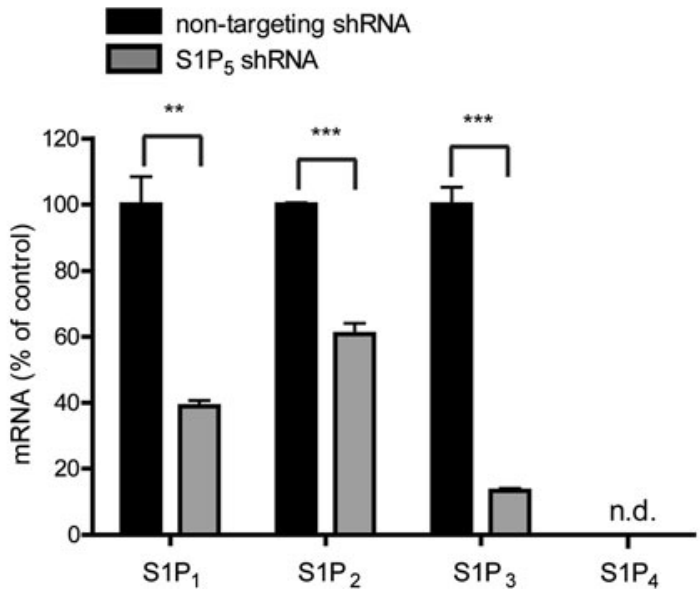

b

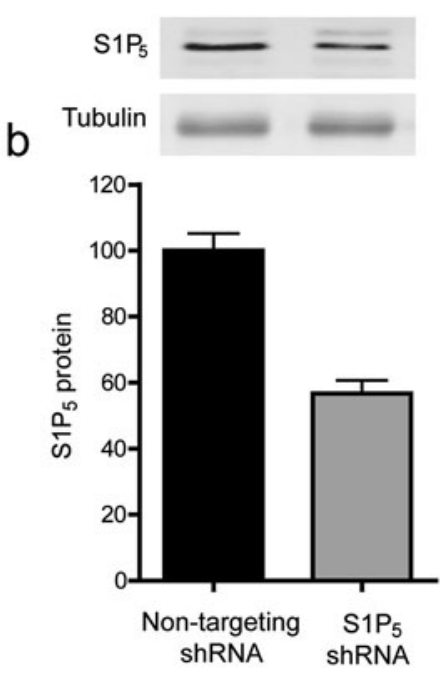

Figure $4 \mathrm{~S} \mathrm{P}_{5}$ knockdown and downstream effects on endothelial S1P receptor expression. (a) A lentiviral shRNA technique was used to knockdown the $\mathrm{S}_{1} \mathrm{P}_{5}$. Treatment of the brain ECs with specific shRNA clone E2 resulted in a non-detectable level of S1P $\mathrm{P}_{5}$ RNA as measured by

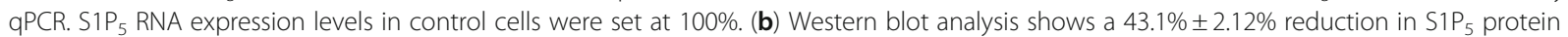
levels when compared to control cells. (c) S1P receptor characterization in $\mathrm{S}_{1} \mathrm{P}_{5}$ knockdown cells show reduction in RNA expression levels of all $\mathrm{S} 1 \mathrm{P}$ receptors where $\mathrm{S} 1 \mathrm{P}_{1}$ is reduced by $61 \%$ (non-targeting control:100.0\% $\pm 8.5, \mathrm{~S} 1 \mathrm{P}_{5}$ knockdown: 38.9\% \pm 1.8 ), S1P 2 by $39 \%$ (non-targeting control: $100.0 \% \pm 0.6, S 1 P_{5}$ knockdown: $60.8 \% \pm 3.3$ ), and $S 1 P_{3}$ by $87 \%$ (non-targeting control: $100.0 \% \pm 5.3 ;$ S1 $P_{5}$ knockdown $13.3 \% \pm 0.8$ ). Again, $\mathrm{S} \mathrm{P}_{4}$ remains undetectable (n.d.) Values represent the mean \pm SEM of $\mathrm{n}=3$. Statistical significance ( $t$-test) is indicated with asterisks: ${ }^{* *} P<0.002$ and ${ }^{* *} P<0.001$.

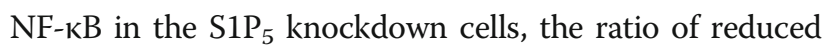
expression of ICAM-1 and VCAM-1 was calculated. It was shown that the ratio of reduction in ICAM-1 gene expression by inhibition of NF- $\mathrm{kB}$ in $\mathrm{S}_{1} \mathrm{P}_{5}$ knockdown cells was increased over 2-fold compared to 1.6-fold in mock cells. Identically, the ratio of reduction in VCAM-1 gene expression by inhibition of NF- $\mathrm{kB}$ in $\mathrm{S}_{1} \mathrm{P}_{5}$ knockdown cells is increased to over 10-fold compared to 7.3-fold in mock cells.

\section{Discussion}

Our present study demonstrates the constitutive expression of the S1P receptor $\mathrm{S} 1 \mathrm{P}_{5}$ by brain ECs, constituting the BBB in human brain and its involvement in both integrity and regulation of the inflammatory status of the brain endothelium. We have delineated a role for $\mathrm{S}_{1} \mathrm{P}_{5}$ in the induction of specific BBB properties such as low paracellular permeability and the expression of key brain endothelial proteins such as tight junction and specific ATP binding cassette and glucose transporter molecules. We have assessed the potential therapeutic improvements upon pharmacological modulation of $\mathrm{S}_{1} \mathrm{P}_{5}$ receptor activity in gaining barrier function. Moreover, the lack of $\mathrm{S} \mathrm{P}_{5}$ provoked a proinflammatory status of brain endothelium as shown by enhanced transendothelial migration of monocytes and increased production of 


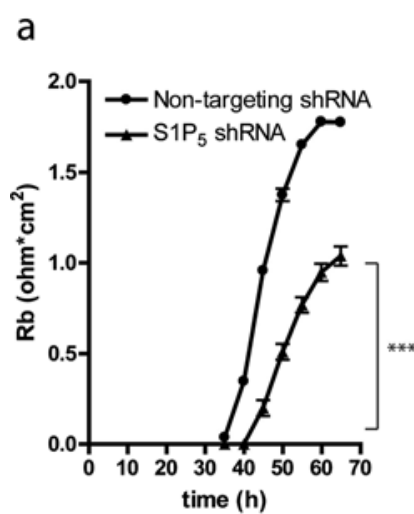

b

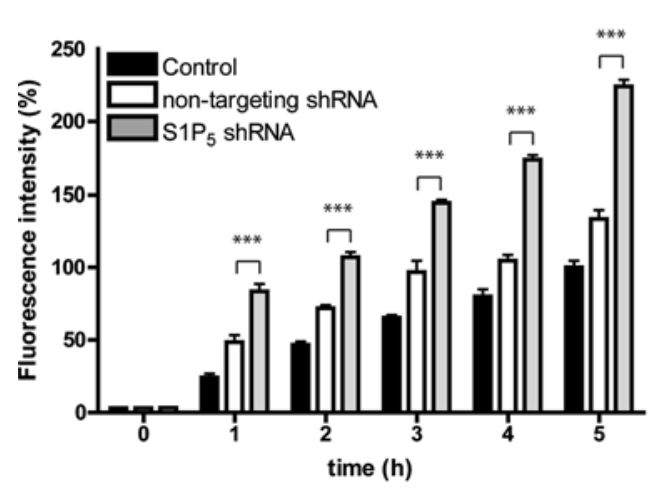

e

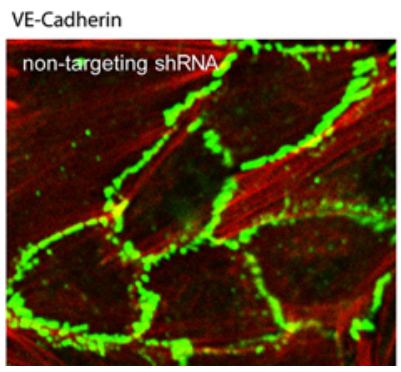

C

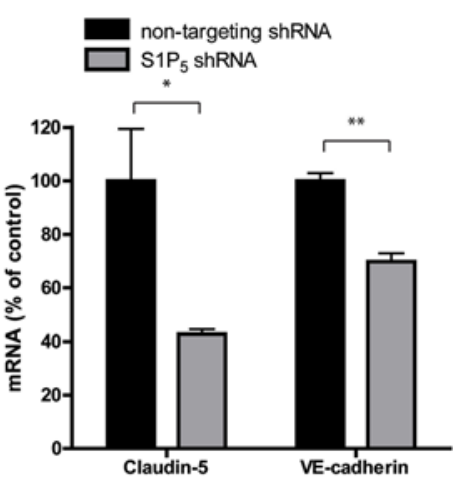

d

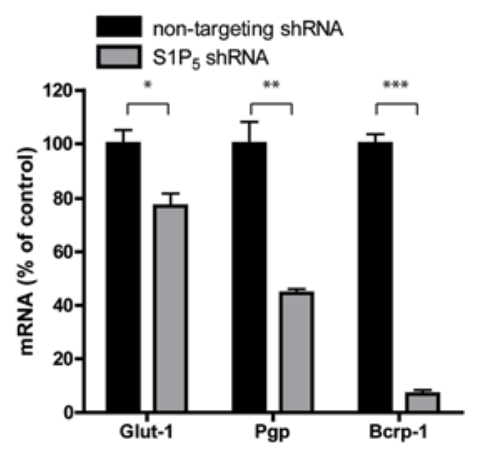

Figure $5 \mathrm{~S} \mathrm{P}_{5}$ regulates several key features of barrier endothelium. (a) ECIS was used to measure the impedance of the brain endothelial monolayer. $\mathrm{S}^{\mathrm{P}} \mathrm{P}_{5}$ knockdown cells $\left(1.0 \mathrm{ohm} . \mathrm{cm}^{2} \pm 0.1\right)$ have over $40 \%$ reduction in TEER compared to mock cells $\left(1.8 \mathrm{ohm} . \mathrm{cm}^{2} \pm 0.02\right)$. Rb values represent the mean \pm SEM of four individual experiments. (b) Paracellular permeability was studied by passive leakage of FITC-dextran molecules (70kD). S1P $\mathrm{P}_{5}$ knockdown cells $(224.1 \% \pm 4.6$ at $5 \mathrm{~h}$ ) were more permeable FITC-dextrans in time compared to control and mock transduced ECs $(133.4 \% \pm 6.1$ at 5 h). Fluorescence intensity values represent mean \pm SEM of four individual experiments with hCMEC/D3. (c) qPCR analysis of tight junction-associated proteins in $\mathrm{S}^{\mathrm{P}_{5}}$ knockdown cells compared to control cells revealed a $57 \%$ decrease in claudin-5 expression (non-targeting control: 100.0\% 19.4; $\mathrm{S1P}_{5}$ knockdown $42.8 \% \pm 1.8, \mathrm{n}=3$ ) and a 30\% decrease in VE-cadherin expression (non-targeting control: $100.0 \% \pm 2.9 ; \mathrm{S}_{1} \mathrm{P}_{5}$ knockdown $69.8 \% \pm 3.2, \mathrm{n}=3$ ). (d) qPCR analysis of transporters expressed at the BBB revealed a $23 \%$ decrease in GLUT-1 expression (non-targeting control: 100.0\% $\pm 5.1 ; \mathrm{S}^{\mathrm{P}} \mathrm{F}_{5}$ knockdown $77.1 \% \pm 4.7, \mathrm{n}=3$ ), 55\% decrease in Pgp expression (non-targeting control: $100.0 \% \pm 8.1 ; \mathrm{S} \mathrm{P}_{5}$ knockdown 44.5\% $\pm 1.60, \mathrm{n}=3$ ), and 93\% decrease in BCRP1 expression (non-targeting control: $100.0 \% \pm 3.5 ; \mathrm{S}^{\mathrm{P}} \mathrm{P}_{5} \mathrm{knockdown}$ $7.0 \% \pm 1.4, n=3$ ). (e) VE-cadherin localization was also studied by immunocytochemistry. Reduced junctional VE-cadherin localization was observed in $\mathrm{S} \mathrm{P}_{5}$ knockdown cells compared to control cells (VE-cadherin, green and F-actin, red). Statistical significance ( $t$-test) is indicated with asterisks: ${ }^{*} P<0.05$, ${ }^{*} P<0.002$ and ${ }^{* *} P<0.001$.

proinflammatory molecules and adhesion molecules for leukocytes, a process which was mediated by NF-kB activation.

Within our findings, we showed the non-selective S1P receptor agonist FTY720P and a selective $\mathrm{S} 1 \mathrm{P}_{5}$ agonist both improve brain endothelial function through the increase of the paracellular resistance in the immortalized human brain EC line, hCMEC/D3. This cell line reflects the key features of primary brain ECs such as high TEER, expression of tight junctions and transporter 


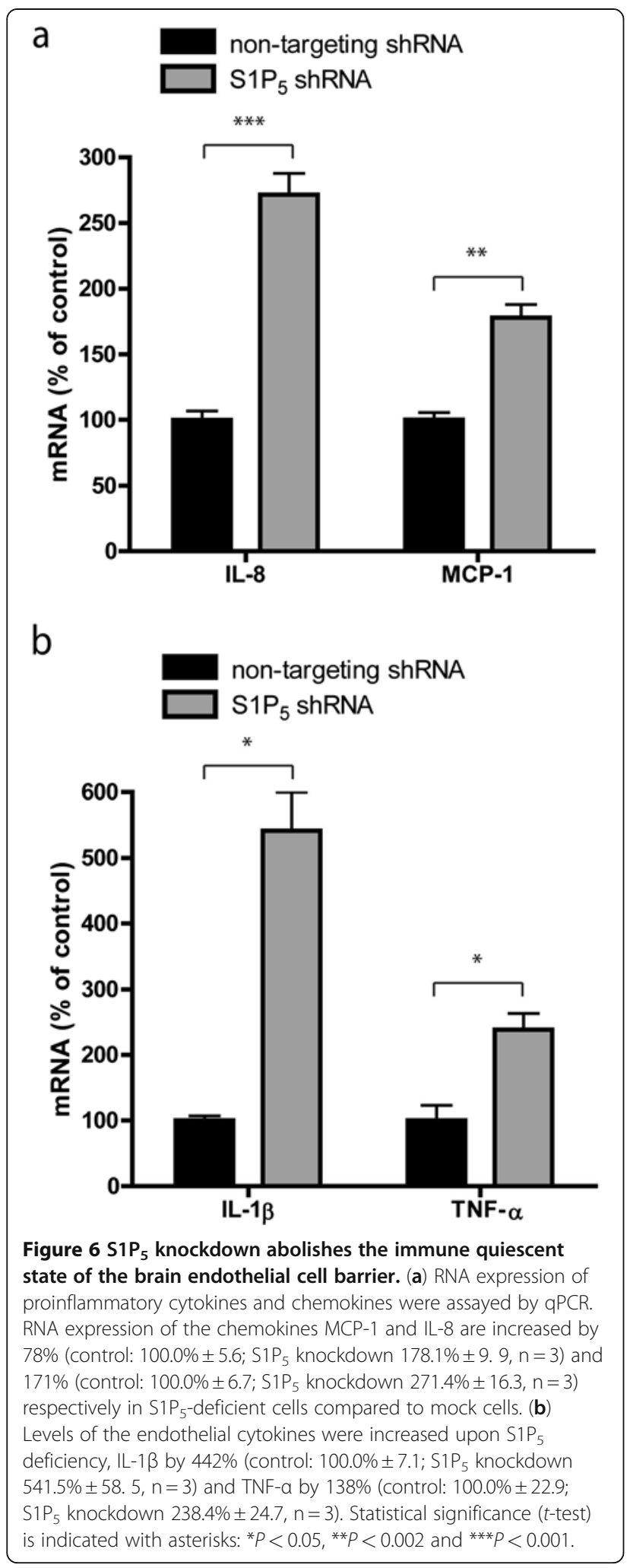

molecules. Our results are in line with previous reports on the endothelial barrier enhancing effect of FTY720P on pulmonary ECs, human microvascular ECs, and human umbilical vein ECs [22,36-38]. However, we are the first to show that selective activation of $\mathrm{S}_{1} \mathrm{P}_{5}$ induces a significant increase in paracellular resistance of brain ECs. Moreover, in concordance with ECs exposed to FTY720P, brain endothelium exposed to a selective $\mathrm{S1P}_{5}$ agonistic compound prevented the transendothelial passage of monocytes in a similar fashion [31]. Enhanced endothelial barrier integrity is probably the result of the enhanced expression of tight junction and adherent junction proteins and their localization at the cell-cell contacts, as was shown in this study. To date, there is emerging evidence that $\mathrm{S}_{1} \mathrm{P}_{1}$ and $\mathrm{S}_{1} \mathrm{P}_{3}$ play an important role in the maintenance of endothelial function. For instance, it has been described that the assembly of junction proteins to the cell-cell junctions is dependent on $\mathrm{S}_{1} \mathrm{P}_{1}$ and $\mathrm{S}_{1} \mathrm{P}_{3}$-induced signaling pathways, involving the small GTP-ases Rac and Rho [39]. Strikingly, in our $\mathrm{S}_{1} \mathrm{P}_{5}$-deficient brain ECs a significant reduction of $\mathrm{S}_{1} \mathrm{P}_{1}$ and $\mathrm{S}_{1} \mathrm{P}_{3}$ was detected, indicating that $\mathrm{S}_{1} \mathrm{P}_{5}$ is involved in the expression of these receptors. Given the importance of $\mathrm{S}_{1} \mathrm{P}_{1}$ and $\mathrm{S}_{1} \mathrm{P}_{3}$ in the maintenance of vascular function, the reduced barrier function of the brain endothelium due to the lack of $\mathrm{S}_{1} \mathrm{P}_{5}$ may also be in part caused by the lack of $\mathrm{S}_{1} \mathrm{P}_{1}$ and $\mathrm{S}_{1} \mathrm{P}_{3}$. Together, our findings point to an important function of $\mathrm{S} \mathrm{P}_{5}$ in the regulation of the barrier phenotype of brain ECs.

Besides improving barrier function, the current report shows that targeting of $\mathrm{S} \mathrm{P}_{5}$ is important for maintenance of the immunoquiescent state of brain ECs. First, our results reveal a prominent role for $\mathrm{S} \mathrm{P}_{5}$ in maintaining low expression levels of leukocyte adhesion molecules, including VCAM-1 and ICAM-1, and several important proinflammatory cytokines and chemokines, such as TNF- $\alpha$ and MCP-1. In addition, $\mathrm{S} \mathrm{P}_{5}$ activation limits monocyte adhesion to and migration over the brain endothelial barrier, which is an initial step in the formation of new MS lesions. Therefore, our findings are of potential interest for future treatment of neuroinflammatory disorders that are marked by a cellular migration across the vessel wall. Modulation of the S1P receptors through FTY720P was shown to be protective in various experimental animal models with neuroinflammation in the brain $[19,40,41]$. Moreover, in other vascular disorders, such as atherosclerosis, FTY720P exerts protective effects by dampening ongoing inflammatory processes in the vascular smooth muscle cells. In the validated experimental animal model for MS, experimental allergic encephalomyelitis FTY720P was either given as a prophylactic, therapeutic or as a rescue agent. In these animals, FTY720P treatment resulted in a delayed onset of disease and reduced disease severity through the induction of lymphopenia. Besides its general immunosuppressive effect, FTY720P treatment also reduced the expression of vascular adhesion molecules and cytokines in the spinal cord of 
treated animals [19]. Moreover, in models of brain ischemia FTY720P was able to reduce infarct size and could, in transient focal cerebral ischemia, positively regulate neurological deficits. Observed beneficial effects were associated with a reduction in activated neutrophil and microglia/macrophage cell numbers and, in line with our results, also with reduced numbers of ICAM-1 positive blood vessels [41]. However, these studies did not investigate the role of endothelial S1P signaling, which may play a crucial role in the early onset of disease [40]. Several in vitro studies support the notion that S1P signaling is relevant in ECs because it was shown that S1P or/and FTY720P limit leukocyte adhesion and transmigration into the vessel wall in the early atherosclerosis pathology. In addition, $\mathrm{S}_{1} \mathrm{P}_{1}$ modulation resulted in reduced endothelial production of TNF- $\alpha$-induced production of proinflammatory chemokines [42-44]. Given that both S1P and FTY720P are general modulators of all S1P receptors, it remains unclear which specific receptor is involved in these processes. More specifically, it is unclear what the role of the brain-specific $\mathrm{S}_{1} \mathrm{P}_{5}$ receptor is in these processes. Our study clearly shows that $\mathrm{S}_{1} \mathrm{P}_{5}$ receptors might play a crucial role in barrier formation and immunoquiescence. Although this study utilized a selective $\mathrm{S}_{1} \mathrm{P}_{5}$ receptor agonist, it is important to identify new more potent and more selective $\mathrm{S}_{1} \mathrm{P}_{5}$ tools to fully elucidate the mechanism by which $\mathrm{S}_{1} \mathrm{P}_{5}$ might exert these effects.

We are also the first to show that NF- $\mathrm{BB}$ underlies the anti-inflammatory activity of endothelial $\mathrm{S}_{1} \mathrm{P}_{5}$. To date, no data exist on the downstream signaling 


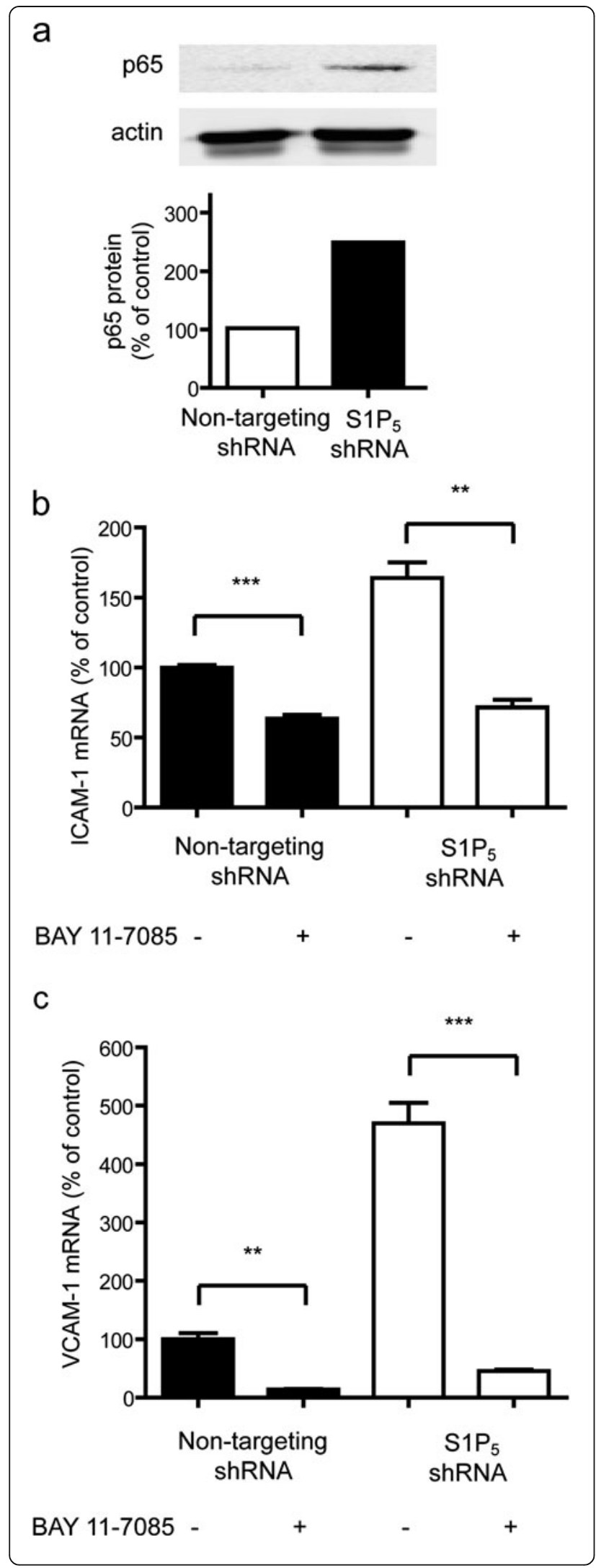

Figure $8 \mathrm{~S} \mathrm{P}_{5}$ mediates immune quiescence of brain endothelial cells by NF-KB. (a) Protein content of p65 in S1P knockdown and control cells was assessed by western blot. The protein expression of control cells was set as $100 \%$. The $\mathrm{S1P}_{5}$ knockdown cells show an increased expression of about $250 \%$ compared to control. The expression of $\mathrm{S} \mathrm{P}_{5}$ was corrected for actin. (b) Mock cells and S1 $P_{5}$ knockdown cells were left unexposed or were exposed to NF-KB inhibitor BAY 11-7085 and ICAM-1 gene expression levels were determined by $q P C R$. Upon exposure to BAY 11-7085 ICAM-1 RNA expression in S1P 5 knockdown cells decreased to approximately the same level as in BAY 11-7085 exposed mock cells. The ratio of reduction in ICAM-1 gene expression by inhibition of NF-KB in $\mathrm{S} \mathrm{P}_{5}$ knockdown cells increased 2.3-fold compared to 1.6-fold in mock cells. (c) Mock cells and S1P $\mathrm{P}_{5}$ knockdown cells were left unexposed or were exposed to NF-kB inhibitor BAY 11-7085 and VCAM-1 gene expression levels were determined by $\mathrm{QPCR}$. Upon exposure to BAY 11-7085 VCAM-1 RNA expression in $\mathrm{S1P}_{5}$ knockdown cells decreased to approximately the same level as in BAY 11-7085 exposed mock cells. The ratio of reduction in VCAM-1 gene expression by inhibition of NF-KB in $\mathrm{S}^{\mathrm{P}_{5}}$ knockdown cells is increased to 10.3-fold compared to 7.3-fold in mock cells. Data are expressed as the mean $\pm \operatorname{SEM}(n=3)$. Statistical significance ( $t$-test $)$ is indicated with asterisks: ${ }^{*} P<0.05,{ }^{* *} P<0.002$ and ${ }^{* * *} P<0.001$.

pathways in ECs upon activation of $\mathrm{S} \mathrm{P}_{5}$. It has been shown that incubation of mouse aortas from type 1 non-obese diabetic mice with S1P reduces VCAM expression and monocyte adhesion to the endothelium. The authors also show that $\mathrm{S1P}_{1}$ is the receptor that mediates this anti-inflammatory response to S1P, which is related to the inhibition of NFkB translocation to the nucleus. In accordance with these findings, our results suggest an anti-inflammatory role for $\mathrm{S} \mathrm{P}_{5}$ in brain ECs. Furthermore, in Chinese Hamster Ovary-K1 cells it was demonstrated that ${\mathrm{S} 1 \mathrm{P}_{5}}_{5}$ expression results in inhibition of extracellular signal-regulated kinase (ERK) activity [45]. Since ERK activity is a potent regulator of NFKBdependent inflammatory responses, this pathway may be responsible for the observed increase in NF- $\mathrm{KB}$ driven of ICAM-1 and VCAM expression in $\mathrm{S} \mathrm{P}_{5}$ knockdown brain ECs.

\section{Conclusion}

Together, our novel and provocative findings emphasize the importance of S1P signaling and in particular $\mathrm{S} \mathrm{P}_{5}$ signaling during health and disease. We demonstrate that endogenous endothelial $\mathrm{S}_{1} \mathrm{P}_{5}$ represents an essential receptor for optimal $\mathrm{BBB}$ function by regulating different aspects of the $\mathrm{BBB}$, including the expression of cell-cell junction proteins and efflux pumps. Importantly, we demonstrate that $\mathrm{S}_{1} \mathrm{P}_{5}$ is essential for maintenance of the immune quiescent state of brain ECs and that this is in part mediated by NF- $\mathrm{KB}$. Our data also reveal the therapeutic potential of $\mathrm{S}_{1} \mathrm{P}_{5}$ agonism during neuroinflammation as $\mathrm{S} \mathrm{P}_{5}$ specifically limits neurovascular inflammation and transendothelial leukocyte infiltration. 


\section{Abbreviations}

ABC: ATP-binding cassette; BBB: Blood-brain barrier; BCRP: Breast cancer resistant protein-1; bFgF: Basic fibroblast growth factor; BSA: Bovine serum albumin; CNS: Central nervous system; DMSO: Dimethyl sulfoxide; EC: Endothelial cell; ECIS: Electrical cell-substrate impedance sensing; EDG: Endothelial differentiation gene; ERK: Extracellular signal-regulated kinase; FCS: Fetal calf serum; GLUT-1: Glucose transporter-1; GPCR: G-protein-coupled receptor; ICAM-1: Intercellular adhesion molecule-1; IL-1 $\beta$ : Interleukin-1 $\beta$; IL-8: Interleukin-8; IRdye: Infrared dye; MCP-1: Monocyte chemoattractant protein-1; MS: Multiple sclerosis; NFkB: Nuclear factor kappa-light-chain-enhancer of activated B cells; NGS: Normal goat serum; PBS: Phosphate-buffered saline; Pgp: P-glycoprotein; qPCR: quantitative PCR; S1P: Sphingosine 1-phosphate; SDS: Sodium dodecyl sulfate; shRNA: short hairpin RNA; TEER: Transendothelial electrical resistance; TNF-a: Tumor necrosis factor-a; VCAM-1: Vascular cell adhesion molecule-1.

\section{Competing interests}

The authors declare that they have no competing interests.

\section{Authors' contributions}

RvD carried out the experiments, analyzed the data and drafted the manuscript. MALP carried out the NFKB analyses. GK performed the transmigration studies. KL, BvhH and SvdP did the culture work and participated in the GPCR analyses. DG provided the shRNA construct. JvH and PvdV were responsible for the human brain tissues and immunohistochemical analyses. EvdK and ER participated in design and coordination, provided useful advice and reviewed the manuscript. AR and HEdV participated in the design and coordination, and wrote and reviewed the manuscript. All authors read and approved the final manuscript.

\section{Acknowledgements}

This work was financially supported by grants from the Dutch MS Foundation (grant MS 05-358a R. van Doorn/HE de Vries, grant MS 05-567, MS 05-358c, J. van Horssen, grant 09-358, M Lopes-Pinheiro), Top Institute Pharma (T2-108 A. Reijerkerk), Netherlands organization for scientific research (VIDI - NWO K. Lakeman)

\section{Author details}

'Department of Molecular Cell Biology and Immunology, VU University Medical Center, P.O. Box 7057, 1007 MB Amsterdam, The Netherlands. ${ }^{2}$ Department of Pediatric Oncology/Hematology, Sophia Children's Hospital, Erasmus University Medical Center, Dr. Molewaterplein 60, 3015 GJ Rotterdam, The Netherlands. ${ }^{3}$ Department of Pharmacology, Abbott GmbH \& Co KG, Knollstrasse 50, Ludwigshafen 67061, Germany. ${ }^{4}$ Department of Pathology, VU University Medical Center, De Boelelaan 1117, 1081 HV Amsterdam, The Netherlands. ${ }^{5}$ Spinoza Centre for Neuroimaging, Royal Netherlands Academy of Arts and Sciences Netherlands Institute for Neuroscience (NIN), Meibergdreef 47, 1105BA Amsterdam, The Netherlands.

Received: 1 February 2012 Accepted: 22 May 2012

Published: 20 June 2012

\section{References}

1. Aronica E, Gorter JA, Redeker S, van Vliet EA, Ramkema M, Scheffer GL, Scheper RJ, van DV, Leenstra S, Baayen JC, et al: Localization of breast cancer resistance protein (BCRP) in microvessel endothelium of human control and epileptic brain. Epilepsia 2005, 46:849-857.

2. Schinkel AH: P-Glycoprotein, a gatekeeper in the blood-brain barrier. Adv Drug Deliv Rev 1999, 36:179-194.

3. Tsukita S, Furuse M, Itoh M: Multifunctional strands in tight junctions. Nat Rev Mol Cell Biol 2001, 2:285-293.

4. Balda MS, Flores-Maldonado C, Cereijido M, Matter K: Multiple domains of occludin are involved in the regulation of paracellular permeability. I Cell Biochem 2000, 78:85-96.

5. Abbott NJ, Ronnback L, Hansson E: Astrocyte-endothelial interactions at the blood-brain barrier. Nat Rev Neurosci 2006, 7:41-53.

6. Vos CM, Geurts JJ, Montagne L, van Haastert ES, Bo L, van DV, Barkhof F, De Vries HE: Blood-brain barrier alterations in both focal and diffuse abnormalities on postmortem MRI in multiple sclerosis. Neurobiol Dis 2005, 20:953-960.
7. Carrano A, Hoozemans JJ, van der Valk P, Rozemuller AJ, van Horssen J, De Vries HE: Amyloid beta induces oxidative stress-mediated blood-brain barrier changes in capillary amyloid angiopathy. Antioxid Redox Signal 2011, 15:1167-1178.

8. Eugenin EA, Clements JE, Zink MC, Berman JW: Human immunodeficiency virus infection of human astrocytes disrupts blood-brain barrier integrity by a gap junction-dependent mechanism. J Neurosci 2011, 31:9456-9465.

9. Avison MJ, Nath A, Greene-Avison R, Schmitt FA, Greenberg RN, Berger JR: Neuroimaging correlates of HIV-associated BBB compromise. J Neuroimmunol 2004, 157:140-146.

10. Kooij G, van HJ, de Lange EC, Reijerkerk A, van der Pol SM, Van Het HB, Drexhage J, Vennegoor A, Killestein J, Scheffer G, et al: T lymphocytes impair P-glycoprotein function during neuroinflammation. J Autoimmun 2010, 34:416-425.

11. Sobel RA, Hinojoza JR, Maeda A, Chen M: Endothelial cell integrin laminin receptor expression in multiple sclerosis lesions. Am J Pathol 1998, 153:405-415.

12. Schreibelt G, Musters RJ, Reijerkerk $A$, de Groot LR, van der Pol SM, Hendrikx EM, Dopp ED, Dijkstra CD, Drukarch B, De Vries HE: Lipoic acid affects cellular migration into the central nervous system and stabilizes blood-brain barrier integrity. J Immunol 2006, 177:2630-2637.

13. Toman RE, Spiegel S: Lysophospholipid receptors in the nervous system. Neurochem Res 2002, 27:619-627.

14. Allende ML, Proia RL: Sphingosine 1-phosphate receptors and the development of the vascular system. Biochim Biophys Acta 2002, 1582:222-227.

15. Brinkmann V, Davis MD, Heise CE, Albert R, Cottens S, Hof R, Bruns C, Prieschl E, Baumruker $T$, Hiestand $P$, et al: The immune modulato FTY720 targets sphingosine 1-phosphate receptors. J Biol Chem 2002, 277:21453-21457.

16. Hasegawa $Y$, Suzuki H, Sozen T, Rolland W, Zhang JH: Activation of sphingosine 1-phosphate receptor-1 by FTY720 is neuroprotective after ischemic stroke in rats. Stroke 2010, 41:368-374

17. Shichita T, Sugiyama $Y$, Ooboshi H, Sugimori H, Nakagawa R, Takada I, Iwaki T, Okada Y, lida M, Cua DJ, et al: Pivotal role of cerebral interleukin-17producing gammadeltaT cells in the delayed phase of ischemic brain injury. Nat Med 2009, 15:946-950.

18. Zhang ZY, Zhang Z, Schluesener HJ: FTY720 attenuates lesional interleukin-17(+) cell accumulation in rat experimental autoimmune neuritis. Neuropathol Appl Neurobiol 2009, 35:487-495.

19. Foster CA, Mechtcheriakova D, Storch MK, Balatoni B, Howard LM, Bornancin F, Wlachos A, Sobanov J, Kinnunen A, Baumruker T: FTY720 rescue therapy in the dark agouti rat model of experimental autoimmune encephalomyelitis: expression of central nervous system genes and reversal of blood-brain-barrier damage. Brain Pathol 2009, 19:254-266.

20. Kappos L, Radue EW, O'Connor P, Polman C, Hohlfeld R, Calabresi P, Selmaj K, Agoropoulou C, Leyk M, Zhang-Auberson L, et al: A placebo-controlled trial of oral fingolimod in relapsing multiple sclerosis. N Engl J Med 2010, 362:387-401.

21. Cohen JA, Barkhof F, Comi G, Hartung HP, Khatri BO, Montalban X, Pelletier J, Capra R, Gallo P, Izquierdo G, et al: Oral fingolimod or intramuscular interferon for relapsing multiple sclerosis. N Engl J Med 2010, 362:402-415.

22. Sanchez T, Estrada-Hernandez T, Paik JH, Wu MT, Venkataraman K Brinkmann V, Claffey K, Hla T: Phosphorylation and action of the immunomodulator FTY720 inhibits vascular endothelial cell growth factor-induced vascular permeability. J Biol Chem 2003, 278:47281-47290

23. Mullershausen F, Craveiro LM, Shin Y, Cortes-Cros M, Bassilana F, Osinde M, Wishart WL, Guerini D, Thallmair M, Schwab ME, et al: Phosphorylated FTY720 promotes astrocyte migration through sphingosine 1-phosphate receptors. J Neurochem 2007, 102:1151-1161.

24. Choi JW, Gardell SE, Herr DR, Rivera R, Lee CW, Noguchi K, Teo ST, Yung YC, Lu M, Kennedy G, et al: FTY720 (fingolimod) efficacy in an animal model of multiple sclerosis requires astrocyte sphingosine 1-phosphate receptor 1 (S1P1) modulation. Proc Natl Acad Sci USA 2011, 108:751-756.

25. Van Doorn R, van Horssen J, Verzijl D, Witte M, Ronken E, Van het Hof $B$, Lakeman K, Dijkstra CD, van der Valk P, Reijerkerk A, et al: Sphingosine 1-phosphate receptor 1 and 3 are upregulated in multiple sclerosis lesions. Glia 2010, 58:1465-1476.

26. van Horssen J, Schreibelt G, Drexhage J, Hazes T, Dijkstra CD, van der Valk $P$, De Vries HE: Severe oxidative damage in multiple sclerosis lesions 
coincides with enhanced antioxidant enzyme expression. Free Radic Biol Med 2008, 45:1729-1737.

27. Weksler BB, Subileau EA, Perriere N, Charneau P, Holloway K, Leveque M, Tricoire-Leignel H, Nicotra A, Bourdoulous S, Turowski P, et al: Blood-brain barrier-specific properties of a human adult brain endothelial cell line. FASEB J 2005, 19:1872-1874.

28. Reijerkerk A, Kooij G, van der Pol SM, Khazen S, Dijkstra CD, De Vries HE: Diapedesis of monocytes is associated with MMP-mediated occludin disappearance in brain endothelial cells. FASEB J 2006, 20:2550-2552.

29. Reijerkerk A, Lakeman KA, Drexhage JA, Van Het HB, Van WY, van der Pol SM, Kooij G, Geerts D, De Vries HE: Brain endothelial barrier passage by monocytes is controlled by the endothelin system. J Neurochem 2012, 121:730-737.

30. Garcia-Vallejo JJ, van DW, Van Het HB, van DI, Engelse MA, Van HV, Gringhuis SI: Activation of human endothelial cells by tumor necrosis factor-alpha results in profound changes in the expression of glycosylation-related genes. J Cell Physiol 2006, 206:203-210.

31. Hanessian S, Charron G, Billich A, Guerini D: Constrained azacyclic analogues of the immunomodulatory agent FTY720 as molecular probes for sphingosine 1-phosphate receptors. Bioorg Med Chem Lett 2007, 17:491-494.

32. Elkord E, Williams PE, Kynaston H, Rowbottom AW: Human monocyte isolation methods influence cytokine production from in vitro generated dendritic cells. Immunology 2005, 114:204-212.

33. De Vries HE, Hendriks JJ, Honing $H$, De Lavalette CR, van der Pol SM, Hooijberg E, Dijkstra CD, van den Berg TK: Signal-regulatory protein alpha-CD47 interactions are required for the transmigration of monocytes across cerebral endothelium. J Immunol 2002, 168:5832-5839.

34. Binnerts $M E$, van $K Y$, Simmons DL, Figdor CG: Distinct binding of $T$ lymphocytes to ICAM-1, -2 or -3 upon activation of LFA-1. Eur J Immunol 1994, 24:2155-2160.

35. Floris S, Ruuls SR, Wierinckx A, van der Pol SM, Dopp E, van der Meide PH, Dijkstra CD, De Vries HE: Interferon-beta directly influences monocyte infiltration into the central nervous system. J Neuroimmunol 2002, 127:69-79.

36. Camp SM, Bittman R, Chiang ET, Moreno-Vinasco L, Mirzapoiazova T, Sammani S, Lu X, Sun C, Harbeck M, Roe M, et al: Synthetic analogs of FTY720 [2-amino-2-(2-[4-octylphenyl]ethyl)-1,3-propanediol] differentially regulate pulmonary vascular permeability in vivo and in vitro. J Pharmacol Exp Ther 2009, 331:54-64.

37. Dudek SM, Camp SM, Chiang ET, Singleton PA, Usatyuk PV, Zhao Y, Natarajan V, Garcia JG: Pulmonary endothelial cell barrier enhancement by FTY720 does not require the S1P1 receptor. Cell Signal 2007, 19:1754-1764

38. Sarai K, Shikata K, Shikata Y, Omori K, Watanabe N, Sasaki M, Nishishita S, Wada J, Goda N, Kataoka N, et al: Endothelial barrier protection by FTY720 under hyperglycemic condition: involvement of focal adhesion kinase, small GTPases, and adherens junction proteins. Am J Physiol Cell Physiol 2009, 297:C945-C954.

39. Lee MJ, Thangada S, Claffey KP, Ancellin N, Liu CH, Kluk M, Volpi M, Sha'afi RI, Hla T: Vascular endothelial cell adherens junction assembly and morphogenesis induced by sphingosine-1-phosphate. Cell 1999, 99:301-312.

40. Keul P, Tolle M, Lucke S, von Wnuck LK, Heusch G, Schuchardt M, der GM Van, Levkau B: The sphingosine 1-phosphate analogue FTY720 reduces atherosclerosis in apolipoprotein E-deficient mice. Arterioscler Thromb Vasc Biol 2007, 27:607-613.

41. Wei Y, Yemisci M, Kim HH, Yung LM, Shin HK, Hwang SK, Guo S, Qin T, Alsharif N, Brinkmann V, et al: Fingolimod provides long-term protection in rodent models of cerebral ischemia. Ann Neurol 2011, 69:119-129.

42. Krump-Konvalinkova V, Yasuda S, Rubic T, Makarova N, Mages J, Erl W, Vosseler C, Kirkpatrick CJ, Tigyi G, Siess W: Stable knock-down of the sphingosine 1-phosphate receptor S1P1 influences multiple functions of human endothelial cells. Arterioscler Thromb Vasc Biol 2005, 25:546-552.

43. Nofer JR, Geigenmuller S, Gopfert C, Assmann G, Buddecke E, Schmidt A: High density lipoprotein-associated lysosphingolipids reduce E-selectin expression in human endothelial cells. Biochem Biophys Res Commun 2003, 310:98-103.

44. Bolick DT, Srinivasan S, Kim KW, Hatley ME, Clemens JJ, Whetzel A, Ferger N, Macdonald TL, Davis MD, Tsao PS, et al: Sphingosine 1-phosphate prevents tumor necrosis factor-\{alpha\}-mediated monocyte adhesion to aortic endothelium in mice. Arterioscler Thromb Vasc Biol 2005, 25:976-981.

45. Niedernberg A, Blaukat A, Schoneberg T, Kostenis E: Regulated and constitutive activation of specific signalling pathways by the human S1P5 receptor. Br J Pharmacol 2003, 138:481-493.

doi:10.1186/1742-2094-9-133

Cite this article as: van Doorn et al: Sphingosine 1-phosphate receptor 5 mediates the immune quiescence of the human brain endothelial barrier. Journal of Neuroinflammation 2012 9:133.

\section{Submit your next manuscript to BioMed Central and take full advantage of:}

- Convenient online submission

- Thorough peer review

- No space constraints or color figure charges

- Immediate publication on acceptance

- Inclusion in PubMed, CAS, Scopus and Google Scholar

- Research which is freely available for redistribution 